\title{
Diagnóstico da degradação ambiental na área do lixão de Pombal - PB
}

\section{Diagnosis of environmental degradation in the dump Area de Pombal - PB}

\author{
Pollyana Bezerra de Azevedo ${ }^{1^{*}}$; José Cleidimário Araújo Leite ${ }^{2}$; Woslley Sidney Nogueira de Oliveira ${ }^{3}$ Franciedna Maria da \\ Silva ${ }^{4}$; Paloma Mara de Lima Ferreira ${ }^{5}$;
}

Resumo: Os lixões urbanos são práticas antigas e constantes nas cidades brasileiras, nas quais os resíduos sólidos são depositados em locais inadequados e sem qualquer tratamento, o que vem a ocasionar impactos para a população, a saúde pública e o meio ecológico. Neste trabalho teve- se como objetivo elaborar um diagnóstico qualitativo da degradação ambiental na área do lixão de Pombal-PB. A metodologia teve por base a realização de visitas de campo, entrevistas aos gestores do município, catadores da área do lixão e moradores no entorno da área em estudo. Fez-se a identificação dos impactos ambientais utilizando-se os métodos Ad Hoc e Check Lists, e proposição de medidas voltadas à recuperação da área. De acordo com os resultados, observou-se que os principais impactos diagnosticados foram: a contaminação do solo, dos recursos hídricos, do ar atmosférico; o aumento dos processos erosivos; redução ou perda total da fauna e flora; riscos aos catadores e impacto na saúde pública. Os fatores mais afetados foram o antrópico, o solo, a fauna, a flora e a paisagem. Propôsse a biorremediação e o reflorestamento para a recuperação da área, cujo uso final indicado foi área de preservação.

Palavras-chaves: Resíduos sólidos, Impactos ambientais, Medidas mitigadoras.

\begin{abstract}
Urban dumps are old and traditional practices in Brazilian cities, in which solid waste are deposited in inappropriate places and without any treatment, what comes to cause impacts to the population, public health and the ecological environment. In this work was aimed to develop a qualitative diagnosis of environmental degradation in the dumpsite area of Pombal-PB. The methodology was based on conducting field visits, interviews with managers of the municipality, waste pickers of dumpsite and residents in the surrounding of the study area. To identify the environmental impacts were used the methods Ad Hoc and Check Lists, and propose measures aimed at recovery of the area. According to the results, it was observed that major impacts were: the contamination of soil, water, atmospheric air; increased erosion; reduction or total loss of fauna and flora; risks to waste pickers and public health impact. The most affected environmental factors were the anthropic, soil, fauna, flora and landscape. The bioremediation technique and reforestation were to recovery the area, whose final use was indicated to preservation.
\end{abstract}

Key words: Solid waste, Environmental impacts, Mitigation measures.

\footnotetext{
*Autor para correspondência 


\section{INTRODUÇÃO}

A sociedade moderna identifica-se com um modelo de desenvolvimento que gera um elevado padrão de produção e consumo, associado ao crescimento populacional e ao processo de urbanização intenso e desordenado, resultando em problemas graves de saneamento básico, principalmente esgoto doméstico e lixo (BRAGA et al., 2002).

Os resíduos sólidos são gerados pelas as atividades humanas e compostos por uma grande diversidade de substâncias e se apresentam no estado sólido ou semissólido, sendo semelhantes de atividades de origem doméstica, industrial, hospitalar, comercial, serviço de varrição e agrícola. Tais resíduos são popularmente conhecido por "lixo", que por definição é tudo aquilo que não é mais útil, funcional e é descartado (PEREIRA NETO, 2007). Vários destinos podem ser dados à sua disposição final, todavia, o pior deles é o "lixão", resultante da simples descarga de lixo sobre o solo, sem critérios técnicos e medidas de proteção ao meio ambiente ou à saúde pública.

As áreas dos lixões ou vazadouros, segundo Pereira Neto (2007), criam condições favoráveis (habitats) à proliferação de vetores (moscas, baratas, ratos e mosquitos), que se multiplicam de forma rápida em razão da grande quantidade de alimento, da facilidade de abrigo. Esses vetores chegam às residências causando doenças, além de facilitarem a contaminação de animais domésticos que ali vivem.

O lixo acumulado produz um líquido denominado de chorume que possui coloração escura com cheiro desagradável e atinge as águas subterrâneas (aquífero, lençol freático) (ARAÚJO et al., 2013). Além disso, ocorre os impactos ambientais do solo, do ar, visuais, sociais e o desequilíbrio da fauna e flora. $\mathrm{O}$ resultado desse conjunto de impactos gera a degradação, que diminui ou impede a capacidade dos recursos ambientais de restabelecer-se naturalmente, ou seja, são alterações significativas.

Os dados da Associação Brasileira de Empresas de Limpeza Pública e Resíduos Especiais (ABRELPE, 2013), revelam que 3.344 municípios ainda fazem usos de locais impróprios para destinação final de resíduos. Desse total, 1.569 municípios utilizam lixões, mesmo esse seja uma forma inadequada de disposição final.

Diante dos riscos oferecidos pela gestão inadequada dos resíduos, surgiu a necessidade de que todas as cidades tenham um adequado gerenciamento de seus resíduos: a coleta, o transporte, o tratamento, bem como a destinação dos resíduos sólidos e a disposição final do rejeito. Em 02 de agosto de 2010 foi promulgada no Brasil a Política Nacional de Resíduos Sólidos (PNRS) pela Lei Federal n 12.305/2010, na qual se determinam as responsabilidades dos geradores, do poder público e aos instrumentos econômicos aplicáveis, sobre a gestão integrada e ao gerenciamento de resíduos sólidos, e se obriga que, no ano de 2014, todos os lixões do Brasil sejam desativados e substituídos por aterros sanitários.

Desse modo, para a desativação do lixão, faz-se necessário um diagnóstico da área, visando avaliar o nível de degradação. Uma vez conhecendo-se as condições ambientais do local, define-se a melhor técnica que deve ser adotada para a recuperação da área.

Para reduzir os impactos ambientais da disposição dos resíduos sólidos urbanos nos solos não basta destinar o lixo coletado a aterros sanitários. Deve-se, também, atuar de maneira a conter a quantidade de lixo a ser descartado e adotar regras, como: reduzir, reutilizar e outras (CALIJURI; CUNHA, 2013).

O município de Pombal - PB está localizado no sertão paraibano e se enquadra no problema apresentado. O lixão está situado próximo a zona urbana e da BR 230, gerando impacto visual e pondo em risco os condutores que transitam sobre a rodovia, devido queimas, presença de urubus e outros animais.

\section{MATERIAL E MÉTODOS}

\section{Localização da área de estudo}

A área de estudo está localizada na cidade de Pombal PB situada na região semiárida do Nordeste brasileiro, no Estado da Paraíba (Figura 2). Encontra-se situada nas coordenadas $06^{\circ} 46^{\prime} 12^{\prime}$ 'S e $37^{\circ} 48^{\prime} 07^{\prime}$ ' W. Pertence à mesorregião do Sertão Paraibano e microrregião de Sousa e suas limitações são os municípios de Cajazeirinhas, São Bentinho, Paulista, São Domingos, Aparecida, Condado e Lagoa, todos no estado da Paraíba. Sua população é estimada em 32.684 habitantes, no ano de 2014, que ocupam uma área de 889 km2 (IBGE, 2010).

Figura1 - Localização do município de Pombal - PB.

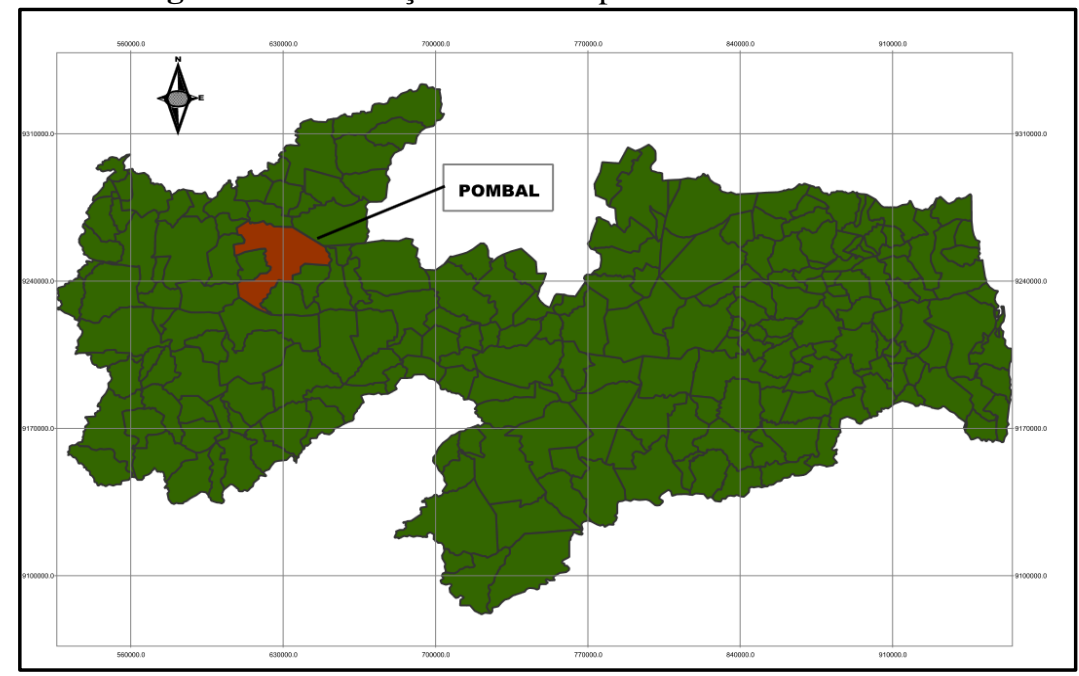




\section{Caracterização da área de estudo}

A descrição da área de estudo foi realizada a partir de pesquisas bibliográficas em livros, trabalhos acadêmicos e técnicos realizados na área, visitas de campo e com uso de ferramentas e técnicas de georreferenciamento, as quais permitiram dados relativos ao diagnóstico da degradação ambiental na área do lixão. As informações foram complementadas com entrevistas informais feitas aos catadores, moradores do entorno do lixão, com órgãos municipais (Diretor de Manutenção das Vias Públicas, Engenheiro Ambiental, Gerente Regional do Cooperar), com objetivo de coletar informações sobre a gestão de resíduos sólidos, além de registro fotográfico.

\section{Georreferenciamento da área}

O georreferenciamento foi realizado por meio de visitas de campo e com auxílio de ferramentas e técnicas de geoprocessamento, para interpretação das imagens de satélites. Fez- se o mapeamento hipsométrico e do índice de vegetação que encontra-se em diferentes estágios de degradação, utilizando GPS (GARMIN 78S) e o Software gvSIG 1.12.

\section{Diagnóstico ambiental da área do lixão}

A identificação e análise dos fatores ambientais na área de estudo foram realizadas a partir de pesquisa de campo, entrevista informal aos gestores do município. Nas visitas de campo, realizou-se a descrição da condição ambiental atual dos fatores ambientais, adicionado a registros fotográficos e entrevista informal. Apresentou-se a descrição dos fatores ambientais para os meios: físico ou abiótico, biótico e antrópico.

\section{Identificação dos impactos ambientais na área de estudo}

A identificação dos impactos ambientais foi realizada a partir do levantamento das principais atividades realizadas na área de estudo e do diagnóstico ambiental.

Os métodos utilizados para identificar os impactos ambientais nesse trabalho foram: Ad Hoc (Método espontâneo) e Check Lists (listagem de controle), na modalidade descritiva.

Identificação dos tipos, causas e consequências da degradação na área

A identificação dos tipos, causas e consequências da degradação na área de estudo foi realizada a partir dos impactos ambientais identificados, entre esses foram selecionados os mais significativos, obtendo auxílio de pesquisas em estudos ambientais acadêmicos e técnicos em áreas semelhantes.

\section{Proposição das medidas voltadas à recuperação da área}

A partir da identificação dos impactos ambientais significativos, foram propostas medidas de mitigação.

As medidas voltadas à recuperação da área em estudo foram propostas a partir de pesquisas na literatura em trabalhos científicos e técnicos de atividades semelhantes a desse estudo.

\section{RESULTADOS E DISCURSÃO}

\section{Caracterização da área de estudo}

A área de estudo compreende o lixão situado na cidade de Pombal - PB. A sua vegetação predominante é a Caatinga, o clima é o semiárido, sendo o período chuvoso no verão.

As águas do município encontram-se nos domínios da bacia hidrográfica do Rio Piranhas, entre a sub-bacia do Rio Piancó e a região do Alto Piranhas. Seus principais tributários são os rios Piranhas e Piancó (CPRM, 2005).

Segundo o engenheiro ambiental do município, Rafael Novaes, o lixão já se encontra instalado na região há quinze anos, atualmente, a área recebe em média 180 toneladas de resíduos sólidos mensalmente, através do georreferenciamento, observou-se que ocupa uma área de aproximadamente 28,2 ha, ocasionando grandes prejuízos de caracteres sociais, econômicos e ecológicos.

Os resíduos gerados do lixão são originados dos serviços públicos de limpeza urbana, dos tipos doméstico e comercial que constituem o chamado lixo domiciliar, que, junto com o lixo público, representam a maior parcela dos resíduos sólidos produzidos nas cidades, incluindo todos os resíduos de varrição das vias públicas, limpeza de galerias, restos de podas de plantas e feira livre, além dos rodoviários, entulhos e de pequenas indústrias instaladas na região.

O serviço de limpeza urbana acontece de forma regular, passando em média três vezes por semana, por meio de caminhões que passam nas ruas recolhendo o lixo residencial e comercial ou sendo depositados nos depósitos de lixos distribuídos no município. Para essa atividade há 5 caminhões e 19 funcionários e não há um estudo dos tipos de resíduos alocados no lixão.

\section{Georreferenciamento da área de estudo}

A seguir, serão apresentados mapas temáticos georreferenciados com algumas características da área do lixão de Pombal - PB.

\section{Mapa de localização da área do lixão}

A instalação da área do lixão pode ser visualizada no mapa de localização da área do lixão e da zona urbana do município de Pombal - PB, apresentado na Figura 2.

O lixão de Pombal - PB está localizado às margens da BR 230, à aproximadamente $400 \mathrm{~m}$, e possui uma distância aproximada de $627 \mathrm{~m}$ da primeira edificação residencial, e bem próxima a açudes, rio e à estação de tratamento de esgoto - ETE. 
Figura 2 - Localização da área do lixão no município de Pombal - PB.

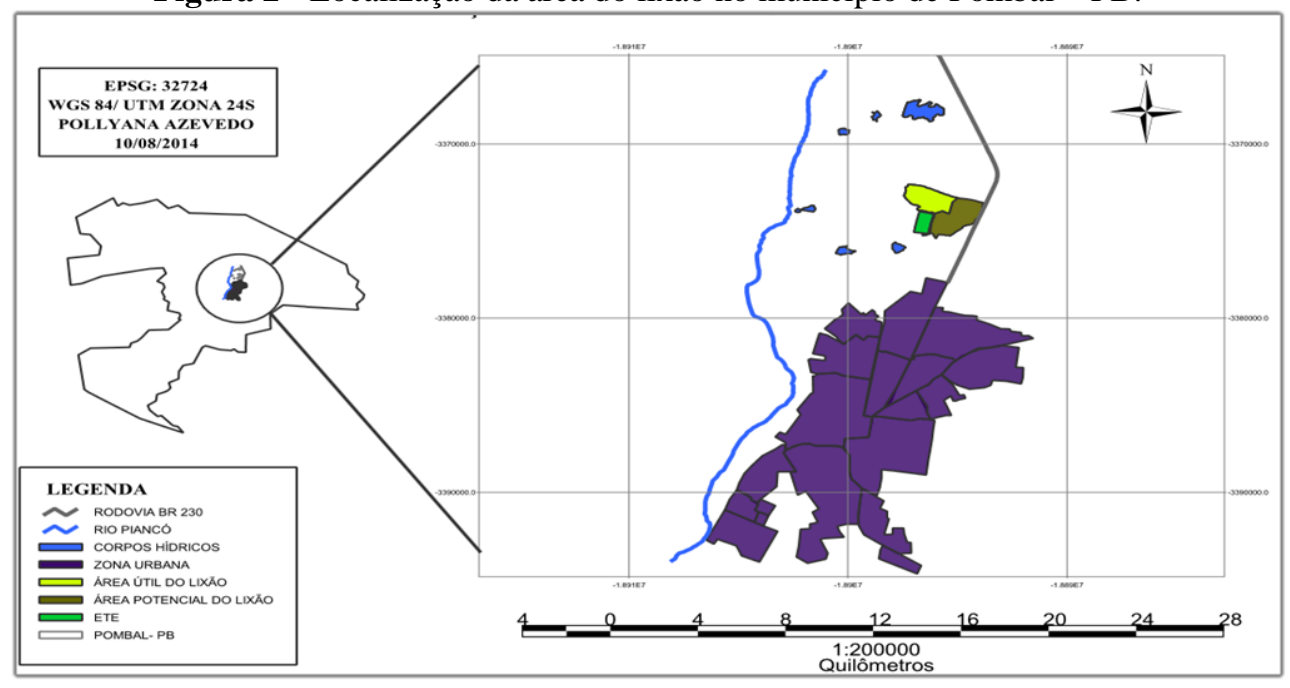

O lixão de Pombal - PB está localizado às margens da BR 230, à aproximadamente $400 \mathrm{~m}$, e possui uma distância aproximada de $627 \mathrm{~m}$ da primeira edificação residencial, e bem próxima a açudes, rio e à estação de tratamento de esgoto - ETE.

\section{Determinação do perímetro do lixão de Pombal - PB}

O perímetro e área útil da área em estudo, encontram-se apresentados na imagem satélite da Figura 3.

Os resíduos sólidos depositados de forma inadequada sobre o solo encontram-se numa área útil com 12,2 ha, mas possuem resíduos espalhadas formando um raio de alcance de $1.577 \mathrm{~m}$, acarretando alterações significativas ao ambiente.

\section{Mapa Hipsométrico da área do lixão}

O mapa hipsométrico representa a elevação de um terreno representada por meio de cores. As cores utilizadas possuem uma equivalência com a elevação do terreno.

Ao se observar o mapa hipsométrico da Figura 4, percebe-se que a área do lixão encontra-se numa altitude entre 200 a 240 metros, estando acima do rio que situa-se a uma altitude entre 160 à $200 \mathrm{~m}$, representada pela cor azul, o que possibilita a ocorrência de assoreamento e contaminação pelo carreamento de sedimentos e produtos altamente poluentes como o chorume. Pela proximidade do lixão com o rio.

Figura 3 - Perímetro e área útil do lixão de Pombal - PB.

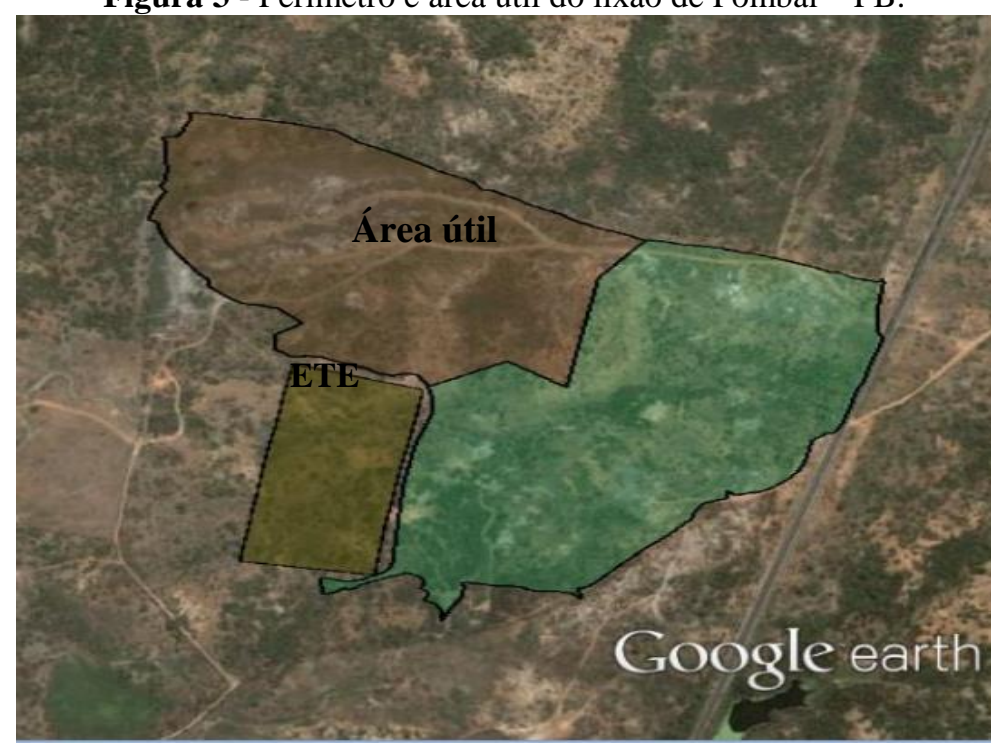

Fonte: Google Earth (2007) 
Figura 4 - Mapa hipsométrico do lixão no município de Pombal - PB.

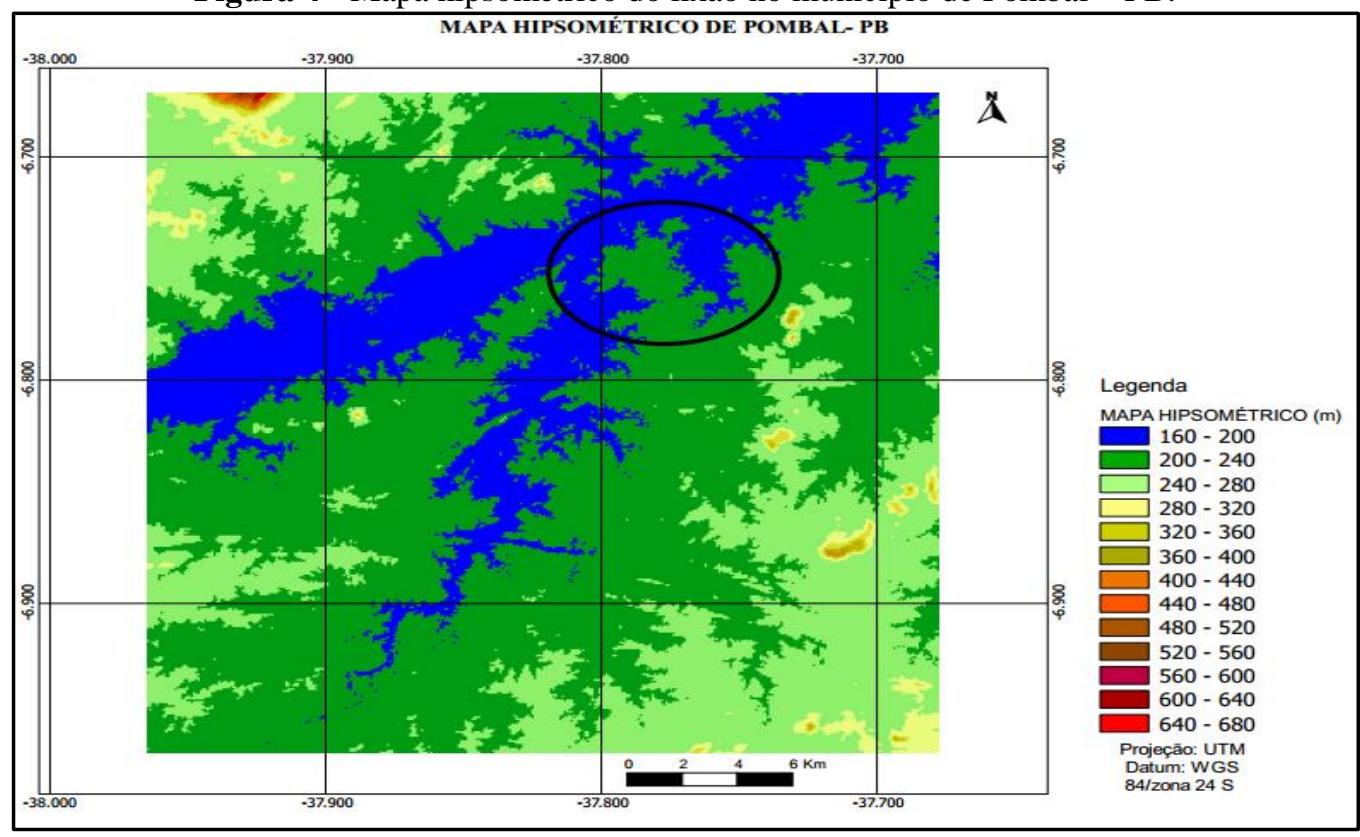

Fonte: Arquivo pessoal, 2014

\section{Diagnóstico ambiental da área do lixão}

Será apresento, a seguir, o diagnóstico qualitativo, nos meios físicos (solo, recursos hídricos, ar e paisagem), biótico (flora e fauna) e antrópico (problemas sociais e saúde pública) na área de estudo. Para melhor descrição da área sobre os efeitos da disposição inadequada dos resíduos sólidos, indicase a realização de análises laboratoriais.

\section{Meio Físico}

\section{Solos}

Nas visitas de campo, percebeu-se que um dos processos mais degradantes do solo é a erosão, que é intensificada com a intervenção humana nesta área, que tem aumentado a exposição do solo, devido a retirada da vegetação. Observaram-se os processos de erosão do tipo laminar e sulcos, ainda pouco profundos, mas que podem evoluir para voçorocas (Figura 5).

Figura 5 - Local com erosão do tipo: (A) laminar; (B) sulcos.
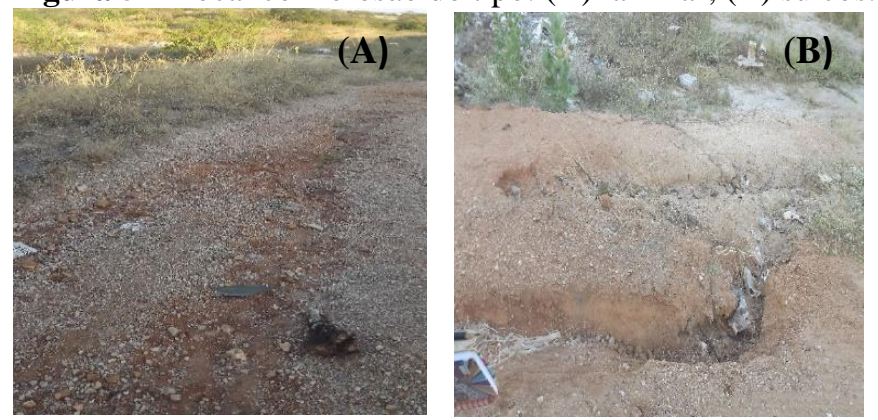

Fonte: Autoria própria, 2014

$\mathrm{Na}$ área percebe-se que a estrutura do solo encontra-se alterada, devido ao depósito inadequado dos resíduos e há uma grande quantidade de resíduos que são classificados como perigosos, e apresentam potenciais de contaminação do solo, tais como: embalagem de óleo de oficina, pneus, lâmpadas, produtos eletroeletrônicos, pilhas e baterias (Figura
6). Esses resíduos são citados no Art. 33, da Lei 12.305/2010, que determina a obrigatoriedade da logística reversa, mediante retorno dos produtos após o uso pelo consumidor, cuja embalagem, após o uso, constitui resíduo perigoso.

Resíduos como pilhas e baterias apresentam em sua composição metais pesados (mercúrio, chumbo, zinco, cádmio, manganês e lítio). Outro resíduo que contém mercúrio são as lâmpadas florescentes. Monteiro et. al. (2001) afirmam que o mercúrio é tóxico para o sistema nervoso humano e, quando inalado ou ingerido, pode causar vários problemas fisiológicos.

Figura 6 - Resíduos classificados como de alta periculosidade encontrada no lixão de Pombal - PB.

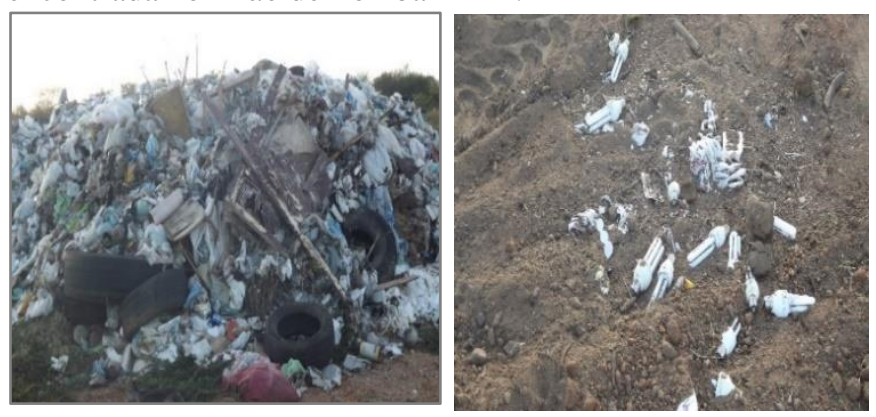

Fonte: Arquivo pessoal, 2014

Além desses resíduos perigosos, foi possível observar materiais infectantes, como os de serviço de saúde (esparadrapo, seringa, embalagem de soro fisiológico, algodão, agulhas), que são descartados por clínicas e farmácias, segundo informações dadas pelos catadores. São resíduos que possuem resolução específica, como a Lei $\mathrm{n}^{\circ}$ 358/ 2005, que dispõe sobre o tratamento e a disposição final dos resíduos dos serviços de saúde e dar outras providências.

Outra característica observada na área de estudo foi a compactação, devido à passagem de veículos pesados como os da coleta de lixo domiciliar, tratores que compactam os resíduos e outros usuários que também utilizam o lixão como destino final de resíduos (Figura 7). A compactação também vem da pressão exercida dos resíduos sólidos, animais, 
catadores sobre o solo excedendo a sua capacidade de suporte à carga.

Figura 7 - Transporte de veículos pesados no lixão de Pombal - PB.
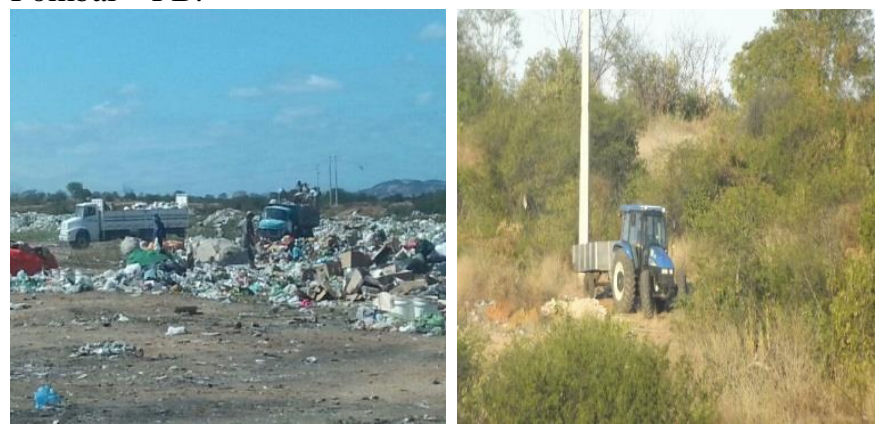

\section{Recursos Hídricos}

A contaminação da água dar-se da seguinte forma: a matéria orgânica depositada no lixão, durante seu processo de decomposição, libera um líquido, conhecido como chorume, que possui contaminantes químicos que se somam à presença de metais pesados (pilhas, baterias, lâmpadas e outros resíduos). Esse líquido infiltra-se no solo, que não passou por nenhum tipo de tratamento de impermeabilização, atingindo o lençol freático e também reservatórios de água superficial próximo ao lixão (rio, açudes) que também são contaminados pelo escoamento superficial das águas no período chuvoso.

Foram observados nas proximidades do lixão o Rio Piancó e dois açudes, situados a pouco mais de 1,15; 0.95; $0,60 \mathrm{Km}$ (Figura 8), que podem estar contaminados, devido ao tempo de existência do lixão, pois há quinze anos o local recebe resíduos sólidos de forma inadequada e, além disso, possui solos rasos com exposição de rochas, o que pode colaborar para a contaminação do lençol freático.

Figura 8 - Corpos hídricos próximos da área do lixão.

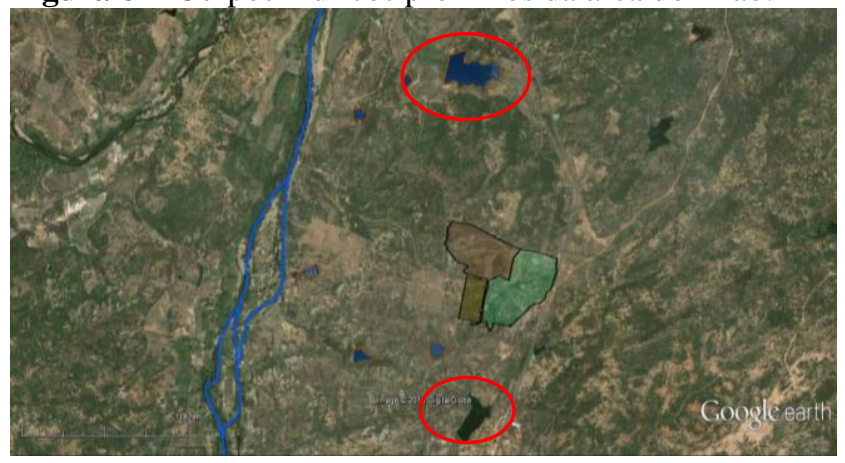

Fonte: Google Earth (2007)

O Rio Piancó é perene, possui mata ciliar abrangendo maior parte do seu comprimento e encontra-se eutrofizado (Figura 9).

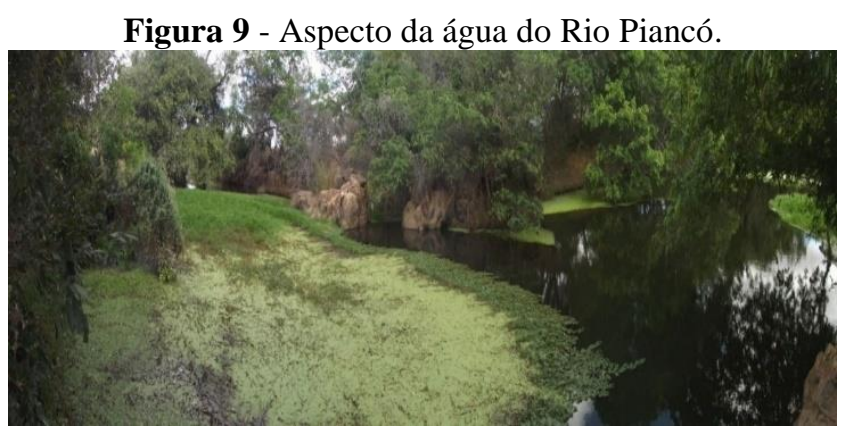

Outro fato a ser observado no local de estudo, são "aberturas artificiais" no solo, formando acúmulos de água que servem como fonte de contaminação. O Gerente Regional Cooperar de Pombal - PB, Luiz Luziel, informou que as aberturas são originadas pela população em busca da areia para construção civil no município e também está sendo utilizada na construção da Estação de Tratamento de Esgoto (ETE).

Figura 10 - Covas no solo do lixão de Pombal - PB.

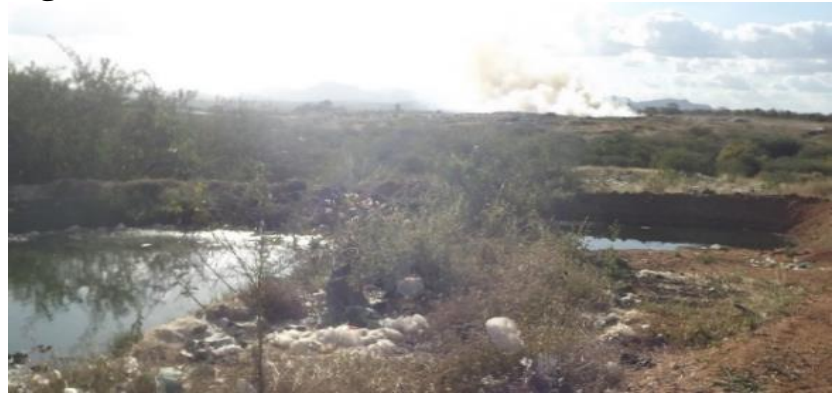

Ar

A composição do ar no lixão é alterada pela emissão de gases proveniente dos resíduos sólidos, onde a material orgânico em decomposição gera gases como, metano $(\mathrm{CH} 4)$, que contribui para o agravamento do efeito estufa, sulfídrico (causam odores desagradáveis) e outros gases (PAGLIUSO, 2008). São gases extremamente inflamáveis que geram risco de queimadas e explosões, além da emissão de gases oriundos de veículos (da coleta do município e outros) e tratores, utilizadas para compactar e espalhar os resíduos pela área.

Observou-se também a prática da queima dos resíduos, com objetivo da diminuição do volume do lixo e afastar animais (urubus, carcarás, etc.) das proximidades do ambiente de trabalho, informações dadas pelos catadores. O lixão, por conter materiais e substâncias altamente tóxicas, que, quando queimadas, liberam gases tóxicos, que se inalados essa fumaça podem vir a causar problemas de saúde. Moradores do entorno da área do estudo reclamam da fumaça, que causa alguns problemas como: cinzas que sujam a casa, doenças respiratórias e outras.

Na Figura 11 (a) mostra-se o início da atividade da queima do lixo que tem como consequência a poluição do ar (Figura b).

Figura 11 - Queima de resíduos na área de estudo (A) e (B).

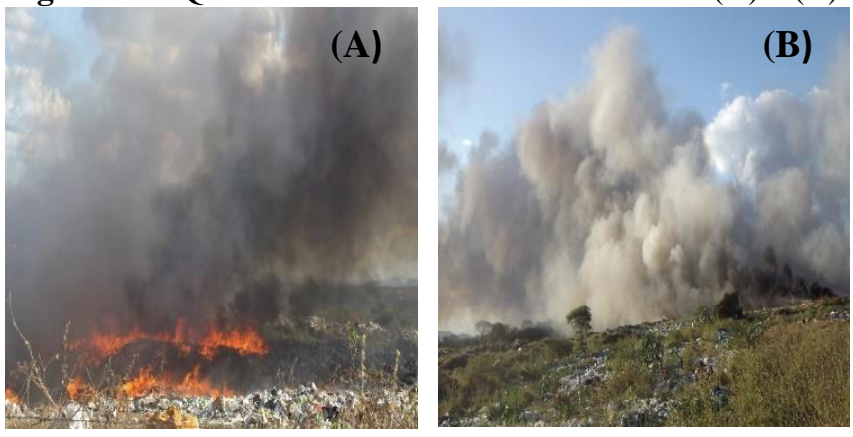

Paisagem

A área de estudo antes composta por vegetação do Bioma Caatinga, foi modificada por resíduos sólidos gerados no município de Pombal-PB, alterando sua paisagem e produzindo impacto visual. 
Foi relatado pelos gestores que há 30 anos já havia indício de resíduos na área de estudo proveniente de moradores que pertenciam aos bairros vizinhos. Um exemplo citado é o Santo Amaro. Porém essa quantidade de resíduo foi aumentando desde a sua implantação, em 1999, pois, anteriormente, a destinação era feita no campo de aviação, próximo a BR 230. Na Figura 12 (a) observa-se a paisagem do ano de 2013 e na Figura 12 (b) do ano 2014.

Figura 12 - Paisagem da área do lixão no ano de 2013 (A) e 2014 (B).
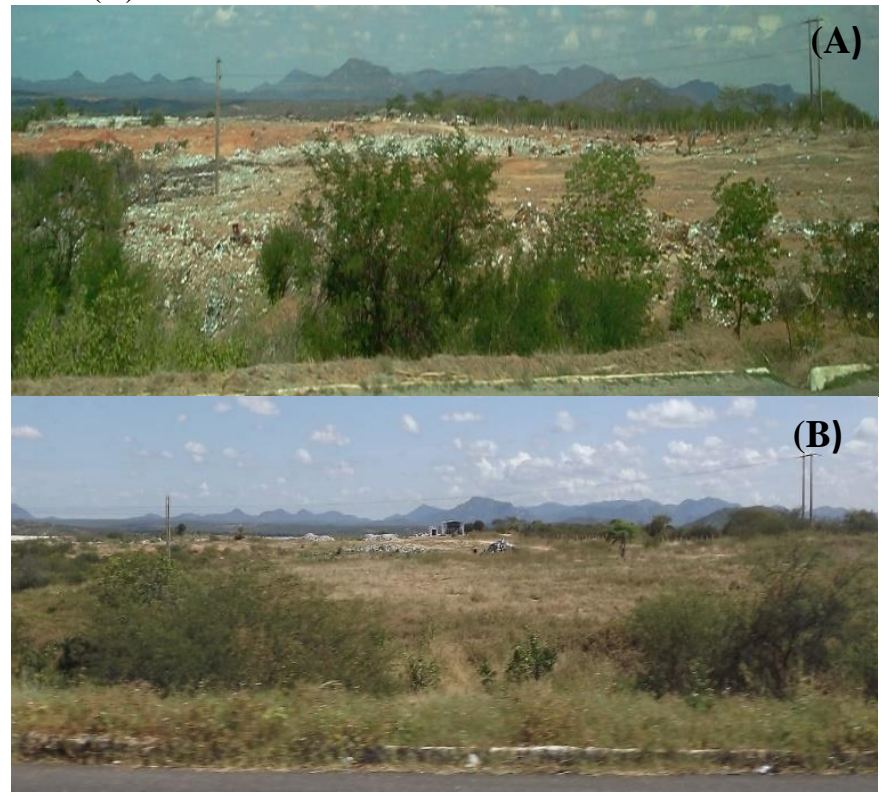

Fonte: Arquivo pessoal, 2013 e 2014

Por estar localizado nas proximidades da BR-230, na saída para Sousa -PB, lixão gera um impacto visual para os visitantes e as pessoas que vivem e transitam por esse trecho. Outro agravante, é o surgimento da presença de veículos carroceiros, que despejam resíduos na entrada do lixão (Figura 13), oriundos da construção civil e pequenas indústrias instaladas na região. $\mathrm{O}$ acumulo de lixo na margem da rodovia atrai urubus, cães e outros animais.
Figura 13 - Resíduos na entrada da área de estudo.

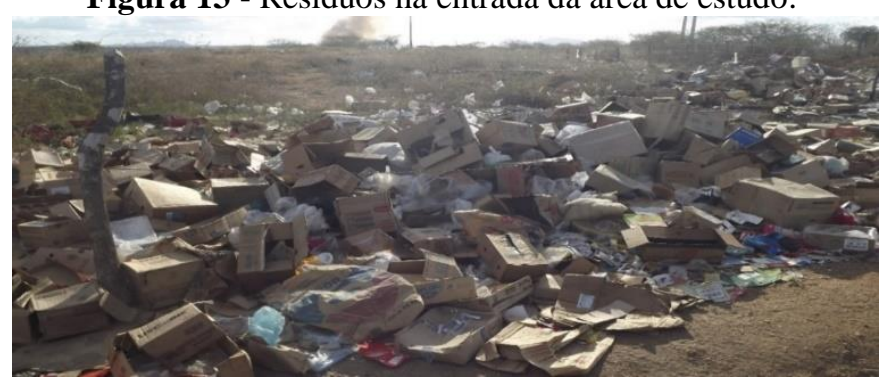

Fonte: Arquivo pessoal, 2014

\section{Meio Biótico}

\section{Flora}

A vegetação é formada por espécies vegetais do Bioma Caatinga, com presença de árvores de pequeno e médio porte. $\mathrm{O}$ desmatamento em grande parte do terreno ocorre para alocação do lixo, gerando a destruição de parte da vegetação do local, além da quantidade de poluentes existente na área, que consequentemente impedem o seu desenvolvimento. $\mathrm{Na}$ Figura 14 apresenta-se algumas das espécies vegetais diagnosticados na área do lixão.

Figura 14 - Espécies vegetais diagnosticadas na área do lixão: (A) Rosa seda (Calotropis procera); (B) Jurema preta (Mimosa hostilis).

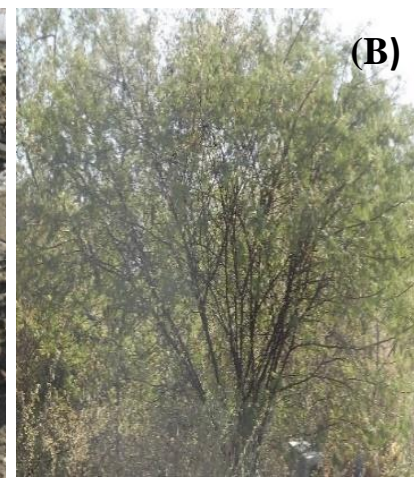

Fonte: Arquivo pessoal, 2014

O mapa índice de vegetação por diferença normalizada (NDVI), assume valores entre -1 e 1 , quanto mais próximo de 1, mais densa é a vegetação, e para corpos hídricos e áreas úmidas o NDVI tem uma resposta negativa (Figura 15).

Figura 15 - Mapa de índice de vegetação na área do lixão de Pombal - PB

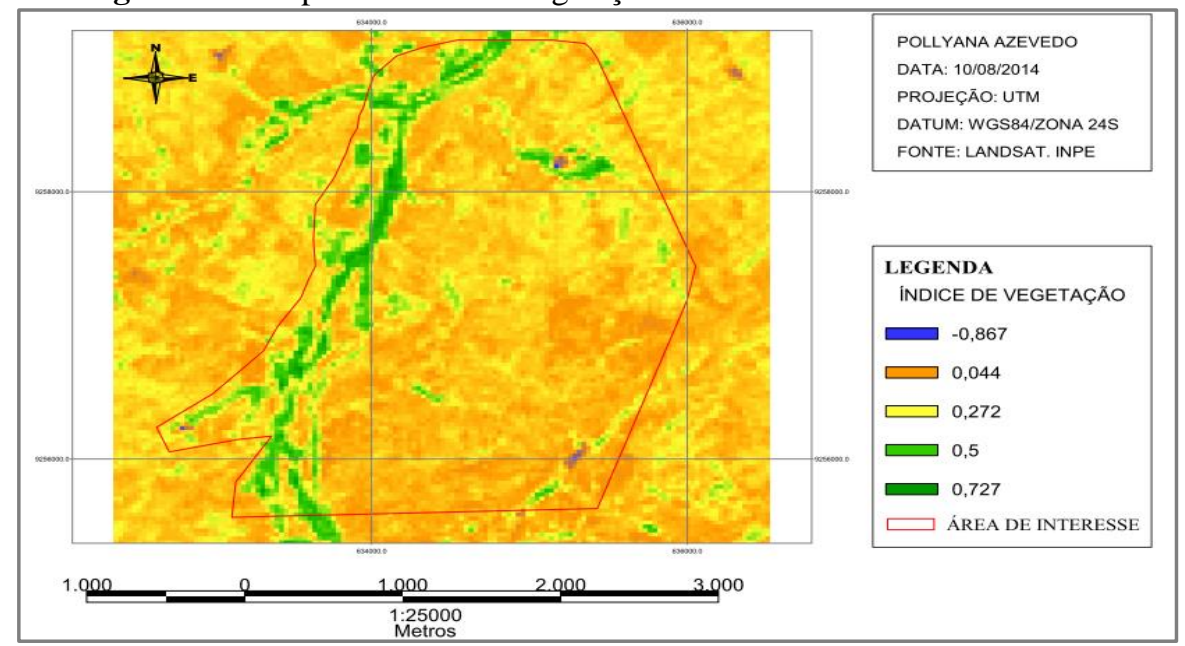


O mapa de vegetação representa modelos resultantes de radiação em imagens de satélites, que quando atinge a superfície terrestre emite reflectância com diferenciadas cores: o azul representa corpos hídricos; marrom, superfície não vegetada; verde escuro, vegetação mais desenvolvida; verde claro, vegetações frágeis e o amarelo, área com pouca vegetação.

Ao analisar o mapa percebe-se o grau de degradação da flora na área de estudo, pela substituição da cobertura vegetal por resíduos sólidos. Essa prática também contribui para o desaparecimento da fauna, e a exposição do solo ainda acarreta a erosão.

No local há grande quantidade de aves "oportunistas", como: carcará e garça, em que tal proliferação ocorreu por se encontrar um ambiente "propício" para se viver. Na Figura 21 apresentam-se algumas espécies da fauna encontradas na área de estudo.

\section{Fauna}

$\mathrm{Na}$ área do lixão, percebe-se que a espécie nativa de animais do local encontra-se reduzida e até extinta, devido à destruição de todo o ecossistema que possibilitava a vida da população animal, obrigando-os dispersarem para outras regiões aumentando o desequilíbrio natural.

No local há grande quantidade de aves “oportunistas”, como: carcará e garça, em que tal proliferação ocorreu por se encontrar um ambiente "propício" para se viver.

Na Figura 16 apresentam-se algumas espécies da fauna encontradas na área de estudo.

Figura 16 - Algumas espécies da fauna natural da área de estudo: (A) Bem-te-vi (Pitangus Sulphuratus); (B) Carcará (Polyborusplancus).

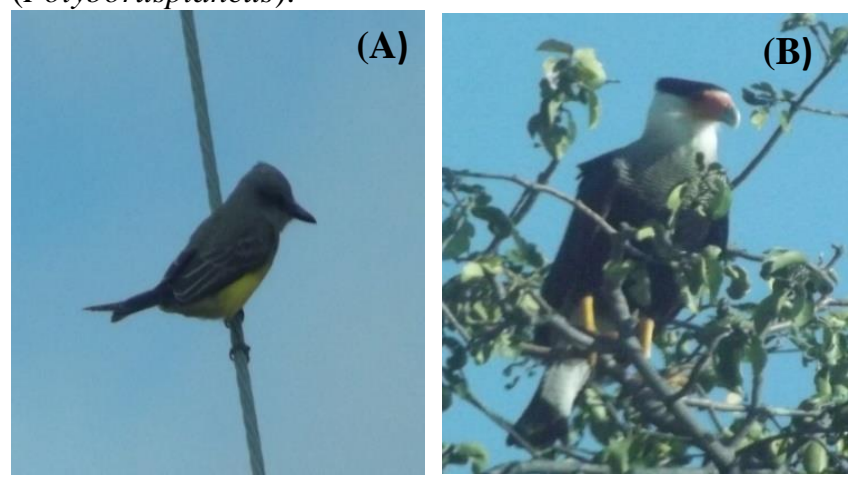

Fonte: Arquivo pessoal, 2014

Além das espécies citadas, surgem espécies exóticas ao ambiente, tais como ratos, baratas, moscas, urubus, cachorros, gatos, garças, bovinos e outros, que podem agir como competidores para espécies nativas da área, além de serem muitas vezes vetores de doenças para outros animais e seres humanos.

Na Figura 17 mostram-se algumas dessas espécies de animais que foram vistas frequentemente durante as visitas de campo.
Figura 17 - Alguns animais invasores na área de estudo: (A) Vaca (Bos taurus taurus); (B) Cachorro (Canis lupus familiaris).

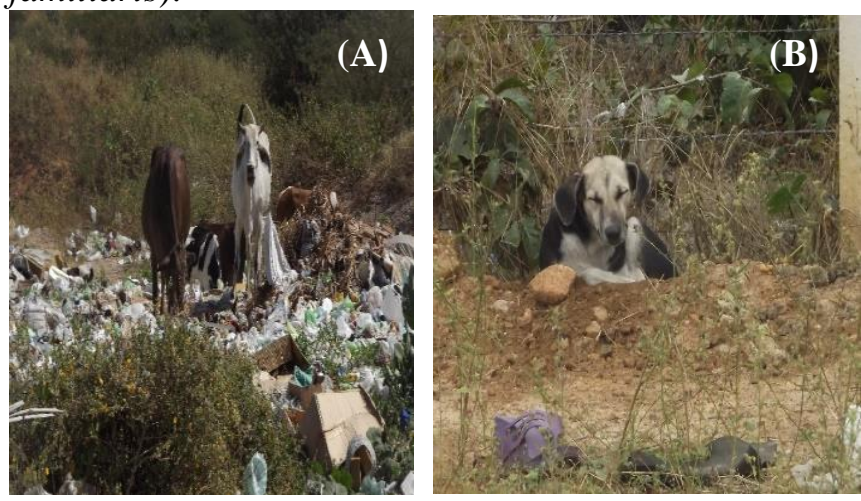

Fonte: Arquivo pessoal, 2014

\section{Meio Antrópico}

\section{Problemas Sociais}

Percebeu-se a degradação social no local de estudo pela presença de catadores na área, entre eles, dois adolescentes (14 e 16 anos) e idosos, que sobrevivem da separação e comercialização dos materiais recicláveis presentes no lixo urbano, o que caracteriza um grave problema social. É um trabalho que muitas vezes envolve toda a família e deixa de fora da escola crianças e adolescentes ficando sujeitos ainda a acidentes. Os catadores declaram que já obteve germes, cortes e que não foram contaminados devido a esse contato. Além disso, verificou-se que não há perspectiva de trabalho a não ser o lixão, pois gostam de trabalhar no local, e muitos trabalham desde o início da sua implantação.

Os gestores informaram a criação da associação dos catadores, quando ocorrer a desativação do lixão, devido a prescrição da Lei 12.305/2010, em que será implantada a educação ambiental no município para o esclarecimento da coleta seletiva, aprimorando o sistema de gestão de resíduos sólidos. Com relação aos catadores, já existem programa de educação ambiental em reuniões mensais para 43 associados cadastrados.

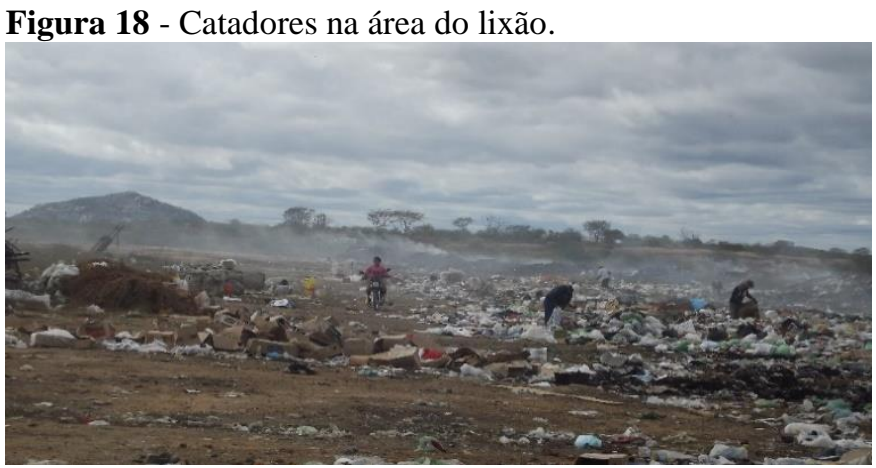

Fonte: Arquivo pessoal, 2014

\section{Saúde Pública}

As espécies exóticas de animais, que se instalaram no lixão, podem transmitir doenças para os catadores, bem como para pessoas que vivem nas proximidades do lixão, pois o mesmo encontra-se perigosamente instalado numa área bem próxima à zona urbana, cerca de $627 \mathrm{~m}$ da primeira edificação, contendo residências, pequenas indústrias (lava 
jato, queijeira, etc). Segundo relatos dos moradores do entorno do lixão, existe grande incidência de baratas, moscas e fumaça, o que acarreta um gasto a mais para a Secretaria de Saúde do Município.

Figura 19 - Área do lixão próximo à zona urbana.

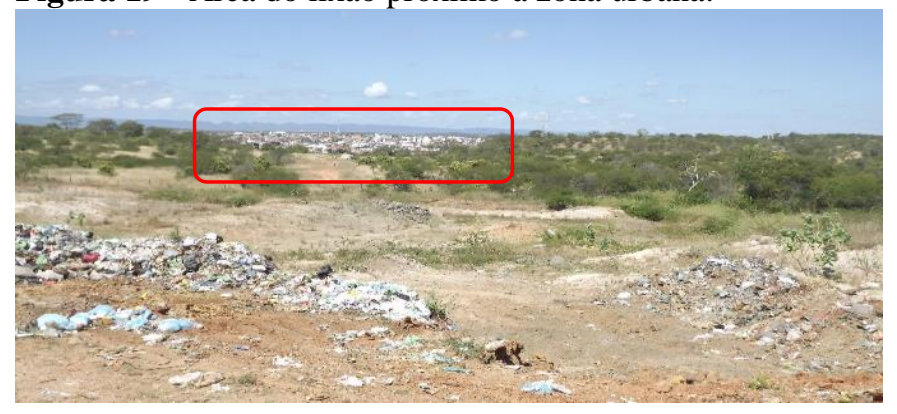

\section{Identificação dos impactos ambientais na área de estudo}

A avaliação dos impactos ambientais decorrentes da instalação do lixão do município de Pombal - PB envolveu a identificação e análise qualitativa dos efeitos ocorridos pelos impactos na área de influência direta, possibilitando a classificação quanto ao seu valor, possibilidade de mitigação, significância, incidência e reversibilidade, tendo a importância

de reuni-los e observar o grau do prejuízo que essa atividade oferece para o meio ambiente.

No Quadro 1 apresenta-se a classificação dos impactos ambientais identificados na atividade realizada na área do "lixão".

Quadro 1- Impactos ambientais e respectiva classificação, no lixão de Pombal - PB

\begin{tabular}{|c|c|c|c|c|c|c|}
\hline \multirow{2}{*}{$\begin{array}{r}\text { Impactos } \\
\text { Ambientais }\end{array}$} & \multicolumn{5}{|c|}{ Critérios de classificação quanto ao } & \multirow[b]{2}{*}{ Fatores Afetados } \\
\hline & Valor & Mitigação & Significância & Incidência & Reversibilidade & \\
\hline $\begin{array}{l}\text { Poluição e/ou } \\
\text { contaminação } \\
\text { do solo }\end{array}$ & $\mathrm{NE}$ & M & S & D e I & Rv & Solo, água e antrópico \\
\hline $\begin{array}{l}\text { Compactação do } \\
\text { solo }\end{array}$ & $\mathrm{NE}$ & M & S & D e I & Rv & Solo, água e fauna \\
\hline $\begin{array}{l}\text { Alteração nas } \\
\text { características } \\
\text { físicas do solo }\end{array}$ & $\mathrm{NE}$ & M & $S$ & D e I & $\mathrm{Rv}$ & \multirow{4}{*}{ Solo e fauna } \\
\hline $\begin{array}{c}\text { Alteração nas } \\
\text { características } \\
\text { químicas do solo }\end{array}$ & $\mathrm{NE}$ & M & S & D e I & $\mathrm{Rv}$ & \\
\hline $\begin{array}{c}\text { Alteração nas } \\
\text { características } \\
\text { biológicas do solo }\end{array}$ & $\mathrm{NE}$ & M & S & D e I & Rv & \\
\hline Erosão acelerado & $\mathrm{NE}$ & M & $S$ & D e I & Rv & \\
\hline $\begin{array}{l}\text { Alteração da } \\
\text { paisagem }\end{array}$ & $\mathrm{NE}$ & M & S & D e I & Rv & Paisagem \\
\hline $\begin{array}{c}\text { Poluição e/ou } \\
\text { contaminação } \\
\text { do Recurso hídrico }\end{array}$ & $\mathrm{NE}$ & M & S & D ou I & Rv & $\begin{array}{l}\text { Água, antrópico, } \\
\text { fauna e flora aquática }\end{array}$ \\
\hline $\begin{array}{l}\text { Alteração do } \\
\text { relevo }\end{array}$ & $\mathrm{NE}$ & NM & $S$ & D & Ir & $\begin{array}{l}\text { Solo, relevo e } \\
\text { paisagem }\end{array}$ \\
\hline $\begin{array}{l}\text { Proliferação de } \\
\text { macro e micro } \\
\text { vetores }\end{array}$ & $\mathrm{NE}$ & M & $S$ & D e I & $\mathrm{Rv}$ & $\begin{array}{c}\text { Antrópico, } \\
\text { fauna e paisagem }\end{array}$ \\
\hline
\end{tabular}


Pollyana B. de Azevedo, et al

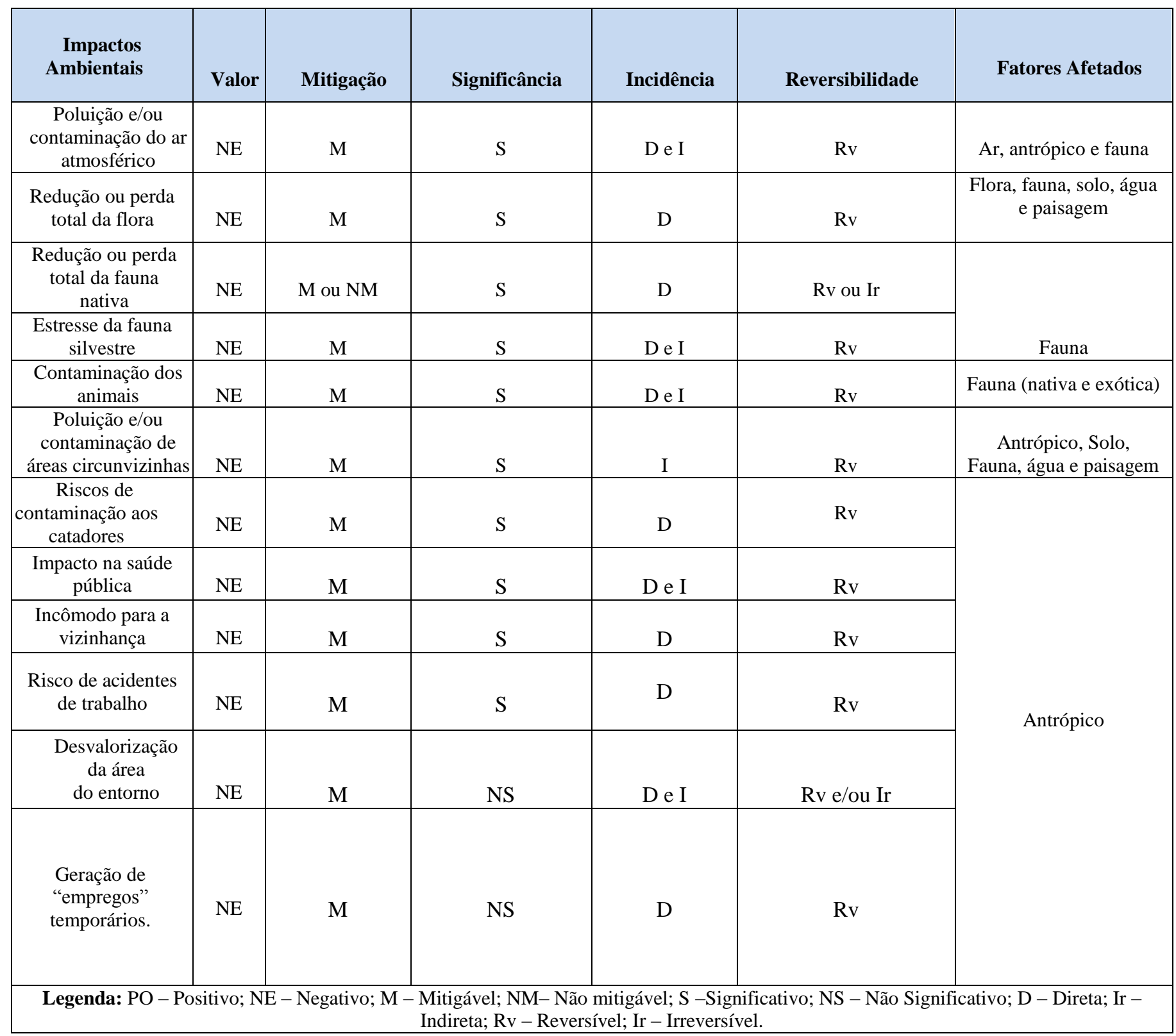

Gráfico 1 - Classificação dos impactos ambientais.

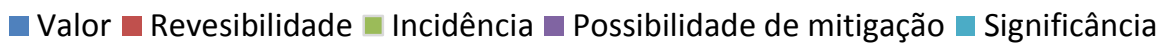

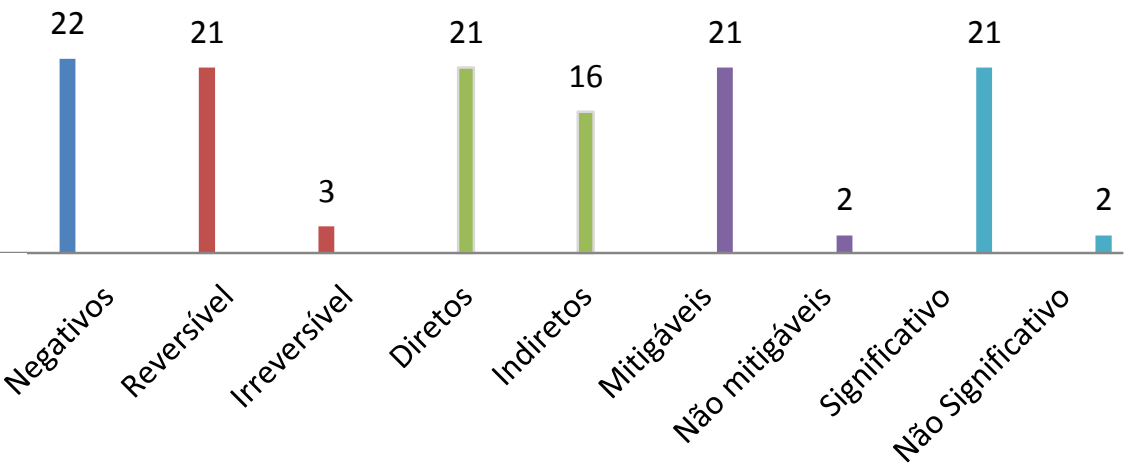

Fonte: Arquivo pessoal, 2014. 
Identificacão dos tipos, das causas e das consequências da degradação na área

Dentre os impactos ambientais citados no Quadro 1, alguns têm o potencial da perda da capacidade de retornar naturalmente ao estado natural, em virtude do depósito contínuo de lixo no solo sem tratamento algum, podendo levar à contaminação dos recursos hídricos, solo e ar atmosféricos. No Quadro 2 é apresentada uma lista com os tipos, classificação, causas e consequências da degradação na área de estudo.

Quadro 2 - Tipos de degradação diagnosticados na área do lixão Pombal - PB.

\begin{tabular}{|c|c|c|c|c|}
\hline $\begin{array}{c}\text { Tipo de } \\
\text { Degradação }\end{array}$ & Classificação & Causa(s) & Consequência(s) & Fator(es) ambiental(is) afetado(s) \\
\hline $\begin{array}{c}\text { Poluição e } \\
\text { Contaminação do } \\
\text { solo }\end{array}$ & $\begin{array}{c}\text { Física, Química e } \\
\text { Biológica }\end{array}$ & $\begin{array}{l}\text { - Natural (chuva) } \\
\text { e/ou Antrópico } \\
\text { (gerenciamento } \\
\text { inadequado de } \\
\text { resíduos sólidos) }\end{array}$ & $\begin{array}{l}\text { - Afeta a saúde dos } \\
\text { vivos; } \\
\text { - Limitação dos } \\
\text { possíveis do solo; }\end{array}$ & Solo, água e antrópico \\
\hline $\begin{array}{c}\text { Compactação do } \\
\text { solo }\end{array}$ & $\begin{array}{c}\text { Física, Química e } \\
\text { Biológica }\end{array}$ & $\begin{array}{l}\text { - Presença de } \\
\text { veículos pesados; } \\
\text { - Pressão exercida } \\
\text { pelos resíduos } \\
\text { sólidos, animais, } \\
\text { catadores sobre o } \\
\text { solo excedendo a sua } \\
\begin{array}{l}\text { capacidade } \\
\text { suporte. }\end{array}\end{array}$ & $\begin{array}{l}\text {-Impermeabilização da água } \\
\text {-Dificulta no } \\
\text { desenvolvimento da fauna. }\end{array}$ & Solo, água e fauna \\
\hline $\begin{array}{l}\text { Contaminação dos } \\
\text { Recursos hídricos }\end{array}$ & Química & $\begin{array}{l}\text { - Natural (chuva) } \\
-\quad \text { Antrópico } \\
\text { (chorume, } \\
\text { elementos químicos } \\
\text { perigosos) }\end{array}$ & $\begin{array}{l}\text { - Afeta a saúde dos } \\
\text { vivos; } \\
\text { - Limitação dos } \\
\text { possíveis da água. }\end{array}$ & Água, antrópico, fauna, flora aquática \\
\hline $\begin{array}{l}\text { Contaminação do } \\
\text { ar atmosférico }\end{array}$ & $\begin{array}{c}\text { Física, Química e } \\
\text { Biológica }\end{array}$ & $\begin{array}{l}\text {-Natural (formação } \\
\text { de gases resultante } \\
\text { das ações das } \\
\text { bactérias da matéria } \\
\text { orgânica) } \\
\text { e /ou } \\
\text {-Antrópica (queima) }\end{array}$ & $\begin{array}{l}\text { - Afeta a saúde dos seres } \\
\text { vivos; } \\
\text { - Riscos de incêndio e } \\
\text { explosão devido a gases } \\
\text { explosivos; } \\
\text { - Odores desagra-dáveis } \\
\text { resultantes da emissão de } \\
\text { gases; } \\
\text { - Contaminação do ar por } \\
\text { gases de efeito estufa. }\end{array}$ & Ar, antrópico e fauna \\
\hline $\begin{array}{c}\text { Tipo de } \\
\text { Degradação } \\
\end{array}$ & Classificação & Causa(s) & Consequência(s) & Fator(es) ambiental(is) afetado(s) \\
\hline $\begin{array}{l}\text { Redução ou perda } \\
\text { total da flora }\end{array}$ & $\begin{array}{c}\text { Física, Química e } \\
\text { Biológica }\end{array}$ & $\begin{array}{l}\text {-Antrópica } \\
\text { (desmatamento) }\end{array}$ & $\begin{array}{l}\text {-Exposição do solo; } \\
\text { - Compactação do solo; } \\
\text { - Degradação da área; } \\
\text {-Extinção animal; } \\
\text { - Perda da deposição } \\
\text { natural de matéria } \\
\text { orgânica oriunda da flora. }\end{array}$ & Flora, Fauna, solo, água e paisagem. \\
\hline $\begin{array}{c}\text { Redução ou perda } \\
\text { total da fauna } \\
\text { nativa }\end{array}$ & Biológica & $\begin{array}{l}\text {-Antrópica (presença } \\
\text { de veículos, } \\
\text { máquinas e pessoas, } \\
\text { desmatamento } \\
\text { queimadas) }\end{array}$ & $\begin{array}{l}\text { - Desequilíbrio na cadeia } \\
\text { alimentar; } \\
\text { - Acidentes com a fauna; } \\
\text { - stresse da fauna. }\end{array}$ & Fauna \\
\hline $\begin{array}{l}\text { Erosivo } \\
\text { acelerado }\end{array}$ & $\begin{array}{c}\text { Física, Química e } \\
\text { Biológica }\end{array}$ & $\begin{array}{l}\text { - Natural (vento, } \\
\text { água) Antrópico } \\
-\quad \text { (desmatamento, } \\
\text { compactação) }\end{array}$ & $\begin{array}{l}\text { - Perda das camadas mais } \\
\text { férteis do solo; }\end{array}$ & Solo e fauna \\
\hline $\begin{array}{c}\text { Impacto na saúde } \\
\text { pública }\end{array}$ & Social & $\begin{array}{l}\text {-Antrópica (fumaça, } \\
\text { macro e micro } \\
\text { vetores). }\end{array}$ & $\begin{array}{l}\text {-Vários tipos de doenças, por } \\
\text { exemplo a respiratória; }\end{array}$ & Antrópico \\
\hline
\end{tabular}


No Quadro 2, observa-se que o meio antrópico, solo, água, flora e fauna são os mais afetados, visto que estes impactos ocorrem em maior quantidade em intensidade na área do lixão.

\section{Estratégias de recuperação da área em estudo}

Com base no diagnóstico ambiental qualitativo, percebese que a área em estudo sofre perturbações na sua estrutura, seja de natureza física, química ou biológica, levando à degradação da sociedade, do solo, dos recursos hídricos, da flora e da fauna.

A Lei 12.305/2010 determina o encerramento das atividades dos lixões, o que necessita de critérios técnicos para essa ocorrência. É explícito nos estudos acadêmicos, trabalhos contendo o fechamento e abandono da área, acarretando o fim da atuação dos catadores, portanto, esse procedimento não é suficiente, pois há continuação de geração de gases, odores e chorume, enquanto houver atividade biológica de resíduos.

A primeira atividade para recuperar uma área é o isolamento, seguido da identificação da degradação existente no local. Após este diagnóstico, são sugeridas medidas de mitigação para diminuir o efeito dos impactos ambientais negativos, e com base na escolha do uso futuro para área degradada, definem-se técnicas (físicas, químicas e biológicas) para recuperação, buscando atender a finalidade, e estabelecer aspectos econômicos, sociais e ecológicos.

A seguir, serão descritas as etapas propostas para recuperação da área degradada do lixão.

\section{Isolamentos da Área}

Inicialmente, torna-se imprescindível eliminar o fator de degradação, ou seja, isolar a área e não praticar qualquer interferência. Intervir no lixão com o intuito de encerrar sua operação, requalificando o ambiente local e, reduzindo os impactos ambientais. Além disso, é necessário a escolha de um local adequado para destinação desses resíduos. Essa destinação final de resíduos deve ser ambientalmente adequada, a exemplo de um aterro sanitário, o que não há em Pombal-PB. Quanto a esta questão, o engenheiro ambiental do município declara que o projeto de criação do aterro sanitário está em elaboração, atendendo as exigências para implantação do aterro sanitário, de acordo a legislação ambiental e Normas Técnicas pertinentes, notadamente a NBR13896/1997 (Aterros de resíduos não perigosos Critérios para projeto, implantação e operação) e a NBR 8419/1992 (Apresentação de projetos de aterros sanitários de resíduos sólidos urbanos).

\section{Retirada de Catadores na Área de Estudo}

Ao desativar o lixão se deve elaborar um planejamento em que ocorra o remanejamento de catadores que buscam seu sustento no local. Uma alternativa é a criação da associação dos catadores no município, podendo mobilizar a sociedade para a coleta seletiva solidária e sensibilizar as pessoas para a importância do trabalho dos catadores, usando a "ferramenta" da Educação Ambiental, além de integrá-los nas atividades do aterro sanitário que está para ser instalado na cidade de Pombal-PB, conforme exigência da PNRS (2010).

\section{- Estimativa do Nível de Contaminação do Solo e Água na Área}

Sabendo das variedades de resíduos sólidos existentes na área, que ocasiona alto percentual de contaminação, faz-se necessário a análise laboratorial do solo e da água (próximo ao lixão) para obter o nível de contaminação, e assim planejar sua recuperação.

Devem ser realizadas análises de metais pesados, tais como Cádmio $(\mathrm{Cd})$, Chumbo $(\mathrm{Pb})$, Cobre $(\mathrm{Cu})$, Cromo $(\mathrm{Cr})$, Manganês (Mn), Mercúrio ( $\mathrm{Hg})$ e Zinco $(\mathrm{Zn})$. Esses fazem parte de resíduos como pilhas, eletrodomésticos, eletroeletrônicos e baterias, etc, que são encontrados em lixões.

Uma área degradada por deposição inadequada de resíduos apresenta um ambiente contaminado com diversos tipos de substâncias perigosas, em que a recuperação consiste na remoção total dos resíduos depositados, transportando-os para um aterro sanitário.

Outras análises a serem feitas são as físicas e biológicas, a exemplo da classe textural e permeabilidade do solo e matéria orgânica, respectivamente.

Para análise de água devem ser realizadas parâmetros físicos (temperatura, turbidez, condutividade elétrica, etc), químico (PH, matéria orgânico, etc) e biológicos (coliformes termotolerantes, total, Cryptosporidium sp, estreptococos fecais e Giardia sp).

Todos esses parâmetros analisados têm seus valores admissíveis na legislação ambiental que deve ser usada como referência para a recuperação da área.

\section{Medidas Mitigadoras}

As medidas mitigadoras constituem o conjunto de ações que visam a reduzir os impactos negativos. Outra forma de controle é a compensação dos impactos não mitigáveis. No Quadro 3 são apresentadas algumas medidas que devem ser adotadas para minimizar os impactos significativos diagnosticados na área de estudo.

\section{- Recomendações para uso da área}

O uso recomendado para a área é a preservação ambiental, que deve, ser obtida com o reflorestamento. Outros usos não são adequados já que próximo a área há uma Estação de Tratamento de Esgoto, o que impede o uso da área para urbanização.

A implantação de aterro sanitário não seria indicada na área devido não atender às exigências da Norma Brasileira NBR13896/1997, a exemplo da distância da zona urbana e corpos hídricos.

\section{- Descontaminação do Solo e da Água}

Caso as análises de água e solo apresentem resultados em desacordo com as da legislação faz-se a descontaminação da área. As estratégias de tratamento a serem implementadas na recuperação da área contaminada devem ser realizadas levando-se em conta a quantidade e composição do contaminante, as características do solo e a profundidade do lençol freático. 
A seleção da tecnologia mais adequada a ser empregada será feita em função da melhor relação custo/eficiência e tempo de tratamento (CUNHA, 2004).

Uma das técnicas indicadas para a descontaminação da área (lixão) é biorremediação, na forma de biorremediação microbiana e fitorremediação, utilizadas para remover os contaminantes e destoxificação do solo. Na biorremediação microbiana utilizam microorganismos e na fitorremediação as plantas, para que o ambiente contaminado se aproxime de sua condição original.
A biorremediação microbiana possui mais eficiência para descontaminar o solo por substâncias orgânicas, em que a retirada dessas substâncias pode ser realizada pela utilização da bioestimulação, bioventilação e a bioaumentação.

A fitorremediação usa plantas e a microbiota para extrair e ou reduzir a toxidade de poluentes no solo, e é mais utilizada no tratamento de solo e água com substâncias inorgânicas. As técnicas a serem usadas são: fitoextração, fitovolatização, rizofiltração.

No Quadro 4 temos exemplos de algumas espécies fitorremediadoras recomendadas para área do lixão.

Quadro 3 - Impactos significativos e medidas de controle.

\begin{tabular}{|c|c|}
\hline Tipo de Degradação & Medidas Mitigadoras \\
\hline Contaminação do solo & $\begin{array}{l}\text { - Retirada dos resíduos do local; } \\
\text { - Retirar a camada de solo contaminada e depositar solo natural na área } \\
\text { escavada, onde o solo contaminado iria para aterro sanitário; } \\
\text { - Usar técnicas de recuperação, como por exemplo, "biorremediação } \\
\text { microbiana" e "fitorremediação". }\end{array}$ \\
\hline Compactação do solo & $\begin{array}{l}\text { - Descompactar o solo e implantar práticas conservacionistas; } \\
\text { - Revegetar outras áreas no lixão, que não estejam compactados. }\end{array}$ \\
\hline Erosão acelerada & $\begin{array}{l}\text { - Limitar o desmatamento; } \\
\text { - Usar técnicas, de controle de erosão (laminar e sulcos), evitando as } \\
\text { voçorocas. }\end{array}$ \\
\hline Contaminação da água & $\begin{array}{l}\text { - Análise dos corpos d’águas do entorno do lixão; } \\
\text { - Eliminação das aberturas do solo, que ocasiona acúmulo de água. }\end{array}$ \\
\hline Contaminação do ar atmosférico & $\begin{array}{l}\text { - Retirada dos resíduos do local; } \\
\text { - Não realizar queimadas dos resíduos. }\end{array}$ \\
\hline Redução ou perda total da flora & $\begin{array}{l}\text { - Reflorestamento; } \\
\text { - Recuperar as áreas de importância ecológica. }\end{array}$ \\
\hline Redução ou perda total da fauna & $\begin{array}{l}\text { - Criar áreas de preservação ambiental, garantindo boas condições para } \\
\text { abrigo da fauna. }\end{array}$ \\
\hline Riscos aos catadores & $\begin{array}{l}\text { - Criar uma associação de catadores; } \\
\text { - Proporcionar programa de educação ambiental. }\end{array}$ \\
\hline Impacto na saúde pública & $\begin{array}{l}\text { - Implantar um plano de gerenciamento de resíduos sólidos; } \\
\text { - Implantar programa de educação ambiental para o município em estudo. }\end{array}$ \\
\hline
\end{tabular}
Fonte: Arquivo pessoal, 2014.

Quadro 4 - Algumas espécies fitorremediadoras recomendadas para área do lixão.

\begin{tabular}{|c|c|c|}
\hline Contaminantes & Espécies & Mecanismos \\
\hline $\mathrm{Zn} \mathrm{e} \mathrm{Cd}$ & $\begin{array}{c}\text { A. Halleri, } \text { Pfoffia sp., } \\
\text { T. caerulenscens }\end{array}$ & Fitoextração. \\
\hline Ase Ni & Pteris sp., B. coddii. Fitoextração. & Fitoextração. \\
\hline $\mathrm{Cd}, \mathrm{Ni}$ e $\mathrm{Zn}$ & Thlaspi caerulescens & Fitovolatização. \\
\hline $\mathrm{Pb}, \mathrm{Cr}, \mathrm{Cd}, \mathrm{Cu}, \mathrm{Ni}, \mathrm{Zn}, \mathrm{Sr}$ & Brassica juncea & Fitoextração. \\
\hline
\end{tabular}

Fonte: Oliveira, 2009.

Todos esses processos necessitam de um monitoramento eficaz para definir se a estratégia de tratamento implementada está se mostrando eficiente ou se está comprometendo, de forma negativa, o ecossistema local.

\section{- Reflorestamento}

Para o reflorestamento é necessário que o solo esteja com sua composição, estrutura, densidade, porosidade e sua fertilidade adequada. Caso não esteja deve-se fazer a devida correção.

Devem-se diagnosticar os tipos de espécies vegetais em torno da área do lixão, para serem usadas na revegetação. Para o preparo do solo é necessária à implantação de espécies do estágio primário encontradas no em torno da área e, em seguida, inserir espécies vegetais de sucessão ecológica secundária e clímax.

No Quadro 5 mostra algumas espécies vegetais que podem ser usadas na regeneração da área em estudo. 
Quadro 5- Espécies vegetais podem ser usadas no reflorestamento

\begin{tabular}{|c|c|c|}
\hline Contaminantes & Espécies & Mecanismos \\
\hline $\mathrm{Zn} \mathrm{e} \mathrm{Cd}$ & $\begin{array}{c}\text { A. Halleri, } \text { Pfoffia sp., } \\
\text { T. caerulenscens }\end{array}$ & Fitoextração. \\
\hline $\mathrm{Ase} \mathrm{Ni}$ & Pteris sp., B. coddii. Fitoextração. & Fitoextração. \\
\hline $\mathrm{Cd}, \mathrm{Ni} \mathrm{e} \mathrm{Zn}$ & Thlaspi caerulescens & Fitovolatização. \\
\hline $\mathrm{Pb}, \mathrm{Cr}, \mathrm{Cd}, \mathrm{Cu}, \mathrm{Ni}, \mathrm{Zn}, \mathrm{Sr}$, & Brassica juncea & Fitoextração. \\
\hline
\end{tabular}

Fonte: Oliveira, 2009

\section{Medidas de Monitoramento}

É de estrema importância realizar o monitoramento para analisar se a vegetação da área está se desenvolvendo, se há espécies de animais de competição no novo ambiente e as demais atividades envolvidas na recuperação da área. O monitoramento deve existir durante e após a recuperação para que se observe se o agente degradante deixou de atuar. Perante o processo de recuperação devem ser feitas análises laboratoriais periódicas para monitorar a qualidade do solo e da água, verificando a situação dos parâmetros em comparação aos níveis toleráveis.

\section{CONCLUSÕES}

A instalação do lixão encontra-se próxima a dois açudes, ao Rio Piancó, à área urbana, a BR 230, o que aumenta os riscos aos recursos naturais e a sociedade.

- A atividade de desmatamento, para disposição dos resíduos sólidos, foi uma das principais causas para exposição do solo, erosão, desaparecimento e extinção da fauna local, alteração da paisagem.

Entre os fatores ambientais diagnosticado qualitativamente, o meio antrópico, solo, água, flora e fauna foram os fatores ambientais mais degradados pelas atividades na área em estudo.

Com esse estudo percebe-se que o município de Pombal - PB expõe dificuldade quanto a competência dos gestores, com relação ao conhecimento prática relacionados ao gerenciamento de resíduos sólidos.

As medidas mitigadoras devem ser usadas para que os impactos ambientais nos componentes solo, recursos hídricos, ar atmosférico, flora, fauna e antrópico sejam reduzidos.

Faz-se necessário a implantação de programas de compostagem e reciclagem para aumentar a vida útil do possível aterro sanitário no município.

$\mathrm{O}$ uso final mais adequado para área foi a Preservação Ambiental, pois próximo a área do lixão há implantação da Estação de Tratamento de Esgoto - ETE, o que não seria indicado para outros usos urbanos.

A atividade antrópica contribuiu bem mais que os agentes naturais na degradação da área de estudo.

\section{REFERÊNCIAS BIBLIOGRÁFICAS}

ASSOCIAÇÃO BRASILEIRA DE EMPRESAS DE LIMPEZA PÚBLICA E RESÍDUOS ESPECIAIS (ABRELP). Panorama dos resíduos sólidos no Brasil 2011.Disponívelem: $<$ http://www.abrelpe.org.br/Panora ma/panorama2011.pdf>. Acesso em: 8 de jul.de 2014.
ARAÚJO, B. G. P.; OLIVEIRA JÚNIOR, E. F.; VIEIRA JUNIOR, A. S. Resíduos Sólidos Urbanos: análise sobre a situação do conjunto Albano Franco - Riachão do Dantas-SE. 2013. Disponível em: <http://fjav.com.br/revista/Downloads/EdicaoEspecialda PosLatoSensuemTerritorioDesenvolvimentoMeioAmbie nte2013/Artigo45_58.pdf>. Acessado em: 15 de jul.de 2014.

BRAGA, B. et al. Introdução à Engenharia Ambiental. 2 ed. São Paulo: Prentice Hall, 2002. 305 p.

BRASIL. Decreto - lei $\mathrm{n}^{\circ}$ 12.305, de 02 de agosto de 2010. Institui a Política Nacional de Resíduos Sólidos. Diário Oficial da República Federativa do Brasil, Brasília, DF, 02 de agosto de 2010.

CUNHA, V.; Caixeta Filho, J. V. Gerenciamento da coleta de resíduos sólidos urbanos: estruturação e aplicação de modelo não-linear de programação por metas. Disponível em: < http://www.scielo.br/pdf/gp/v9n2/a04v09n2>. Acessado em: 15 de jul.de 2014 .

FOGLIATTI, M. C.; FILLIPO, S.; GOUDARD, B. Avaliação de impactos ambientais: Aplicação aos Sistemas de Transporte. 2. Ed. Rio de Janeiro: Interciência: 2004, 249p.

INSTITUTO BRASILEIRO DE GEOGRAFIA E ESTATÍSTICA (IBGE). Cidades. 2010. Disponível em: <http://www.ibge.gov.br/cidadesat/painel/painel.php?co dmun=251210 > . Acesso em: 10 de jul.de 2014 .

MONTEIRO, J. H. P et. al. Manual de Gerenciamento Integrado de Resíduos Sólidos. Elaborado pelo IBAM - Instituto Brasileiro de Administração Municipal. Rio de Janeiro, 2001, p. 204.

NBR 8419: Apresentação de projetos de aterros sanitários de resíduos sólidos urbanos. Rio de Janeiro, 1992.

NBR 13896. Aterros de resíduos não perigosos Critérios para projeto, implantação e operação. Rio de Janeiro, 1997.

OLIVEIRA, D. L. 2009. Plantas Nativas do Cerrado uma Alternativa para Fitorremediação. 2009. Disponivel em: <http://revistas.pucgoias.edu.br/ index.php/estudos/ /article/viewFile/670/824>. Acesso em: 5 de julho de 2014. 
PAGLiUSO, J. D.; REGATTIERI, C. R. Estudo do aproveitamento da energia do biogás proveniente da incineração do chorume para a geração de eletricidade. Revista Brasileira de Ciências Ambientais, v. 16, 2008. p. 7. Disponível em: <http://www.rbciamb.com.br/images/online/10_artigo_5 _artigos102.pdf >. Acessado em: 20 de julho de 2014.

PEREIRA NETO, J. T. Gerenciamento do lixo urbano: Aspecto técnicos e operacionais. 1. ed. Minas Gerais: Miro Saraiva, 2007. p. 13 - 51.

PHILIPP JR, A.; ROMERO. M. A.; BRUA, G. C. Curso de gestão ambiental. 2. Ed. São Paulo: Manole, 2004, $1047 p$.

SÁNCHES, L. E. Avaliação de Impacto Ambiental: Conceitos e Métodos. São Paulo: Oficina de Textos, 2008, 495p.

SERVIÇO GEOLÓGICO DO BRASIL (CPRM). Projeto Cadastro de Fontes de Abastecimento por Água Subterrânea: Diagnóstico do município de Pombal. Recife: CPRM/PRODEEM, 2005, 23 p. 